УДК 811.163.41'367.622

https://doi.org/10.18485/kij.2017.64.3_4.8

ДИНА П. ТОМИЋ АНИЪ

Универзитет у Београду

Филолошки факултет
Оригинални научни рад

Примљен: 03. 11. 2017.

Прихваћен: 13. 12. 2017.

\title{
ПРОТОТИПИЧНЕ ГРАДИВНЕ ИМЕНИЦЕ **
}

\begin{abstract}
Пошто критеријуми за одређивање градивних именица на које наилазимо у граматикама српског језика често нису недвосмислено примењиви за утврђивање градивности код појединачних именица, у раду покушавамо да идентификујемо прототипичне градивне именице, које би могле да послуже као оријентири у граматичкој, али и семантичкој анализи ове групе именица. Посебну пажњу посвећујемо семантичким елементима важним за особину градивности. Коментаришући резултате анкете коју смо спровели трагајући за прототипичним градивним именицама, скрећемо пажњу на проблем разграничења класе градивних именица и осталих класа у оквиру поделе именица по значењу.
\end{abstract}

Кључне речи: градивност, градивне именице, nomina materialia, прототипичне градивне именице, значење градивних именица, подела именица по значењу, singularia tantum.

\section{1. Увод}

У оквиру поделе именица по значењу, градивне именице се издвајају у посебну класу због специфичног граматичког понашања, које се огледа у дефектној категорији броја, због чега се оне често наводе и међу именицама singularia tantum. Како је М. Ивић приметила, „могућност/немогућност супротстављања једнине множини стоји, у ствари, у непосредној корелацији с могућношћу/немогућношћ партикуларизовања, тј. уочавања појединачног” (Ивић 1980: 1), односно, „под градивним појмом треба, дакле, разумети све оно што се перципира као некаква маса, а не као уобличен предмет” (Ивић 2008: 15). Поставља

\footnotetext{
*dina@fil.bg.ac.rs
}

** Овај рад је настао у оквиру пројекта Српски језик и његови ресурси: теорија, опис и примене (бр. 178006), који у целини финансира Министарство просвете, науке и технолошког развоја Републике Србије. 
се питање $ш т а$ се и зашто перципира као маса, што је и предмет овог рада. У циљу проналажења додатних смерница за одређивање класе градивних именица (и њихово разграничење према осталим класама), проблему градивности ћемо приступити са становишта теорије прототипа, а у проналажењу прототипичних градивних именица послужићемо се анкетом.

При покушају „разврставања” именица на заједничке/збирне/градивне..., чим се зађе изван најчешће навођених примера у граматикама, наилази се на проблеме који се не могу лако разрешити уз помоћ трију најчешће помињаних критеријума при одређивању класе градивних именица.

Први критеријум је семантички. У граматикама најчешће стоји да „градивне именице означавају и највећу и најмању количину (неке) материје”, при чему се уместо речи „материја” јављају и „градиво”, „твар”, „нешто што се употребљава за храну, пиће, грађу, уопште за живот” или „различите врсте материјала" (уп. Ломпар 2016: 79-80).

Други критеријум је морфолошки. Према В. Ломпар (2016: 81), у свим граматикама од Стевановићеве (1979) наводи се да оне немају множину (тј. када је имају, онда мењају значење); оне се најчешће карактеришу као singularia tantum. Тако је и у Нормативној граматищи П. Пипера и И. Клајна, са напоменом да „множина градивних и апстрактних именица није уобичајена, а када се употреби, обично се односи на различите врсте исте материје, нпр. минералне воде Србије [...]” (Пипер-Клајн 2014: 58).

Трећи критеријум је синтаксички. Градивне именице не могу улазити у синтагме са нумеричким квантификаторима, тј. нумеричка квантификација је могућа само уз употребу партикуларизатора: „Када уз градивну или збирну именицу треба употребити број, онда се у конструкцију с таквим именицама уводи партикуларизатор, као назив јединице мере, нпр. две кутије шибица [sic!], три чаше воде, четири гл ав ице купуса" (Пипер-Клајн 2014: 59).

Друга два критеријума тичу се, дакле, граматичког понашања градивних именица, које индукује семантика ових именица описана у првом критеријуму. Требало би, претпоставили смо, идентификовати извесну архисему „градивности” код свих именица које су градивне у примарном значењу, а која би их сврстала у „ширу тематску групу речи” (Д. Гортан-Премк, према Драгићевић 2010: 70), али и семе нижег ранга, што није нимало једноставно, нарочито када узмемо у обзир да „лексема не улази у ЛСГ [лексичко-семантичку групу речи - Д. Т. А.] целокупном својом значењском структуром, већ једним од својих значења" (Драгићевић 2010: 237).

Јасно је да градивне именице не могу бити властите (односно, када се употребе за именовање, као нпр. у топониму Пескови, свакако престају бити градивне). Такође, оне су увек конкретне. ${ }^{1}$ Међутим, граница између заједничких, збирних и градивних често је прилично мутна. М. Ивић каже да „има чак појава

\footnotetext{
${ }^{1}$ Из угла традиционалне поделе именица по значењу, све градивне именице су конкретне. Многе апстрактне именице се понашају слично градивним, што је последица концептуализације (уп. нпр. именицу љубав и њену множину), али ми ту појаву нећемо обрађивати, као ни питање које из ње проистиче - да ли градивне именице могу бити и апстрактне.
} 
које су по самој својој природи прелазног, збирно-градивног карактера" и наводи сламу као пример² (Ивић 2008: 15). Градивне именице су, дакле, оно што Р. Драгићевић назива „категоријом са нејасним границама” (Драгићевић 2010: 81), што онда значи да би нам као оријентир у разумевању категорије градивности могао послужити прототип (односно више њих), са којим би се поредили остали чланови групе.

\section{2. Анкета о градивним именицама}

За потребе истраживања прототипичних градивних именица спровели смо анкету у форми on-line упитника користећи Google Forms (https:/www.google. com/forms), који омогућава једноставан пренос података у Microsoft Excel 2007. За обраду података коришћени су програми Microsoft Excel 2007, SPSS 15.0 и библиотека у програмском језику Java за Preference Data Mining, за рад са пре-

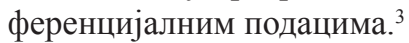

У упутству је испитаницима скренута пажња да анкету треба да ураде за што мање времена и да не трагамо за тачним и нетачним одговорима, како бисмо добили именице којих се прво сете, тј. да не би претерано размишљали или одговоре тражили у граматикама, а они су углавном пратили упутство: од 110 испитаника, њих 74 је урадило задатак за мање од 5 мин., 31 испитанику је требало између 5 и 10 мин., а свега 5 испитаника је анкету попуњавало више од 10 мин.

У анкети су испитаници замољени да наведу да ли су некада студирали српски језик (понуђени су одговори: Тренутно студирам српски језик. - Завршио/-ла сам студије српског језика. - Никада нисам студирао/-ла српски језик.) и годину рођења.

Затим је требало да наведу 20 градивних именица (Наведите једну градивну именииу. - Наведите још једну градивну именииу...), при чему попуњавање упитника није могло да се оконча без минимално 10 наведених одговора. Сматрали смо да је минимум од 10 потребан да бисмо могли говорити о прототипичним именицама и њиховом рангирању (те тако, заправо, добити прототипичну ранг-листу), а уједно смо хтели и одвратити оне испитанике којима би задати минумум представљао проблем (јер би остало питање да ли их не знају више или, што је вероватније, нису имали стрпљења да анкету попуне до краја). С друге стране, захтев са више од 20 именица би, чини нам се, одвратио и оне мотивисаније, а не би допринео нашем циљу - проналажењу прототипичних, односно репрезентативних градивних именица.

2 Збирно-градивне именице М. Ивић помиње и када говори о поврћу: „Већина назива за поврће у нашем језику испољава граматичко понашање градивних, односно збирно-градивних именица - не подаје се плурализовању” (Ивић 2008: 16), а за воће каже: „По изузетку се догађа да облици једнине добију, уз нормалну сингуларску, и збирно-градивну интерпретацију” (Ивић 2008: 17).

3 За помоћ у осмишљавању анкете и обради података посебну захвалност дугујемо Наталији Билишков, Драгани Петровић и Ловри Илијашићу, чија стручност далеко превазилази нашу у поменутим областима. 


\section{1. Структура испитаника}

Од 113 попуњених анкета, обрадили смо њих 110. Два испитаника нису навела задати минимум од 10 различитих градивних именица и њихови одговори нису обрађени, а искључен је и један испитаник чији су скоро сви одговори садржали „градивност”, али су сви наведени одговори били синтагме, а не именице.

Табела 1. Структура анкетираних испитаника

\begin{tabular}{|l|c|c|c|c|}
\hline ИСПИтАНИЦИ & $\begin{array}{c}\text { студирају } \\
\text { српски језик } \\
\text { (С) }\end{array}$ & $\begin{array}{c}\text { завршили } \\
\text { студје срп- } \\
\text { ског језика } \\
\text { (П) }\end{array}$ & $\begin{array}{c}\text { никада нису } \\
\text { студирали } \\
\text { српски } \\
\text { језик (H) }\end{array}$ & укупно \\
\hline број испитаника & 42 & 25 & 43 & $\mathbf{1 1 0}$ \\
\hline $\begin{array}{l}\text { просечно } \\
\text { одговора (од 20) }\end{array}$ & 17,10 & 19,44 & 17,40 & $\mathbf{1 7 , 7 4}$ \\
\hline $\begin{array}{l}\text { погрешних } \\
\text { одговора }\end{array}$ & $0,84 \%$ & $0,41 \%$ & $3,21 \%$ & $\mathbf{1 , 6 4 \%}$ \\
\hline
\end{tabular}

\section{3. Градивне именице у анкети}

У одговорима смо добили 246 различитих именица (од чега 26 погрешних - око 10\%), и то у 1.952 појављивања (свега 32 погрешна - 1,64\%). Дакле, корпус којим смо се служили састојао се од 220 градивних именица ${ }^{4}$ (при чему се градивност не мора испољавати у њиховом основном значењу) у 1.920 појављивања. Азбучним редом, то су:

азот (2), алева паприка (1), алкохол (2), алуминијум (16), амарант (1), арматура (1), арсен (1), асфалт (2), база (1), бакар (41), балега (1), барут (1), бензин (6), бетон (17), бибер (12), блато (12), босиљак (1), брашно (89), бронза (7), бундева (1), ваздух (19), ванилин-шећер (1), вата (3), ватра (2), вегета (3), ветар (1), вино (32), вискоза (1), вода (93), водоник (1), восак (4), вуна (41), гас (3), гвожђе (45), гипс (1), глина (12), гориво (1), грађа (1), гранит (2), графит (2), грах (1), гриз (2), грожђе (1), гума (19), густин (2), дијамант (3), дим (3), дрво (60), дуван (1), ђубриво (1), еластин (2), жар (1), желатин (1), жива (3), жито (7), жица (3), жуч (1), зачин (2), земља (49), злато (56), иловача (1), иње

${ }^{4}$ Међу њима су и три лексикализована споја: један је градивна именица са описним придевом, који због финалног -ев подсећа формом на градивне придеве, али нема везе с њима (алева паприка), други је градивна именица са односним придевом, који се због промене у акценту и постпозиције осећа као атрибутив (сода бикарбона), а трећи је са именицом ванилин у атрибутској функцији, за коју би многи вероватно помислили да је градивни придев (ванилин-шећер) (уп. РСЈ под одговарајућим одредницама). Иако оваквих спојева међу лексемама које се одликују градивношћу има много, они за сада остају изван оквира нашег истраживања. Сматрали смо, међутим, да их не треба искључити из грађе. Занимљиво је напоменути да су се сва ова три примера нашла код истог испитаника. 
(1), јаје (3), јечам (2), јогурт (4), јод (1), какао (8), калијум (1), камен (50), карбид (1), картон (6), кафа (14), каша (1), кашмир (1), кварц (1), квасац (3), кекс (2), керамика (2), ким (1), киноа (1), киселина (1), кисеоник (2), киша (2), кобалт (1), кожа (16), конац (1), конопља (1), коса (2), кост (1), крв (2), креда (1), креч (23), крзно (3), кромпир (2), кукуруз (2), купус (1), лава (1), лан (8), лед (4), лепак (2), лим (4), лимун (1), лимунада (1), лимунтус (1), магла (1), магма (1), мајонез (1), мак (1), малтер (19), маст (16), мастило (3), материјал (1), мед (9), меласа (1), мермер (10), месинг (2), месо (5), метал (25), млеко (63), муљ (1), мусли (1), најлон (2), натријум (2), нафта (13), олово (15), омекшивач (1), опека (2), оригано (1), памук (42), папир (12), паркет (1), пена (1), пепео (2), перје (2), песак (96), петролеј (1), пиво (7), пиринач/рижа (6), пирит (1), пластелин (1), пластика (45), платина (3), платно (6), плиш (7), плута (2), пљувачка (1), поливинил (1), полиестер (2), поморанџа (2), порцелан (1), прашак (3), прашина (3), презла (1), претоп (1), просо (1), пудинг (1), путер/маслац (3), пшеница (2), раж (1), ракија (4), руда (1), рузмарин (1), салама (1), сало (1), сатен (2), свила (35), сено (1), силикон (1), силицијум (1), синтетика (2), сир (3), сирће (11), сируп (1), слама (4), сланина (1), слуз (1), снег (14), со (63), сода бикарбона (1), сок (7), сомот (4), спанаћ (1), сребро (49), стакло (47), стиропор (2), сулфат (1), сумпор (2), сунђер (2), сусам (2), текстил (1), тесто (7), тканина (1), трава (3), угаљ (16), угљеник (3), уље (53), фарба (1), фиберглас (1), филц (1), хартија (1), хелијум (2), хељда (1), хидроген (1), хлеб (3), хлор (1), храстовина (2), целулоза (2), цемент (36), цигла (24), цимет (1), цинк (5), цреп (5), чај (1), челик (22), чоколада (5), шећер (86), шлаг (3), шљунак (21), шодер (2), штоф (1)

У зависности од тога да ли су и када испитаници студирали српски језик, наишли смо на минимална варирања у одговорима, а прилично уједначени су били и одговори испитаника различитих узраста. Овај податак је важан због чињенице да анкета заправо показује „протипичне научене примере за градивне именице” (јер смо морали употребити термин, са којим су се испитаници сретали у формалном образовању), али чињеница да нема много варирања између оних који су о градивним именицама размишљали давно и оних који су на неки начин и даље у контакту са тим термином сведочи о релевантности одабраног метода.

\section{1. Ранг-листа прототипичних градивних именица}

У 1.920 појављивања, првих 18 именица покрива више од 50\% појављивања, а сваку од њих је навело бар 40 од 110 испитаника. Међу њима се посебно издвајају прве четири (песак, вода, брашно и шећер), што се види из приложене табеле.

Табела 2. Ранг-листа по броју појављивања

\begin{tabular}{|c|c|c|c|c|c|}
\hline песак & 96 & дрво & 60 & стакло & 47 \\
\hline вода & 93 & злато & 56 & гвожђе & 45 \\
\hline брашно & 89 & уље & 53 & пластика & 45 \\
\hline шећер & 86 & камен & 50 & памук & 42 \\
\hline млеко & 63 & сребро & 49 & бакар & 41 \\
\hline со & 63 & земља & 49 & вуна & 41 \\
\hline
\end{tabular}


Између 21 и 40 пута појавиле су се именице ичемент, свила, вино, метал, цигла, креч, челик и иљунак. Између 11 и 20 појављивања имале су именице: ваздух, малтер, гума, бетон, маст, кожа, алуминијум, угаљ, олово, кафа, снег, нафта, папир, глина, бибер, блато и сирће. Између 5 и 10 испитаника навело је именице: мермер, мед, какао, лан, тесто, жито, бронза, сок, пиво, плиш, картон, платно, пиринач (рижа), бензин, чоколада, иреп, изинк, месо. Осталих 160 именица (од укупно 220) имало је мање од пет појављивања.

Наведена листа, добијена једноставним пребројавањем појављивања, упоређена је са ранг-листом која се најмање разликује од свих осталих, ${ }^{5}$ што се добија израчунавањем Kendall tau distance између добијених одговора ${ }^{6}$ и применом методе Local Kemenization за одређивање преференција у ранг-листама. Прототипична ранг-листа - она која се најмање разликује од свих осталих, била би:

песак-вода-брашно-шећер-млеко-со-дрво-уље-злато-земла-гвожђе-сребро-камен-стакло-пластика-бакар-иемент-памук-вино-вуна

Као што видимо, и применом техника за одређивање преференција добијамо такорећи исти резултат, што потврђује релевантност добијених података.

\section{4. Семантичке категорије}

Прототипична ранг-листа коју смо добили занемарује важну чињеницу да ми о градивним именицама размишљамо у семантичким категоријама (односно класама или, боље речено, тематским групама), што су и испитаници показали у својим одговорима, па су брашно, вода, шећер, со и млеко ближи једни другима у појединачним одговорима, док се бетон, малтер, циила и креч такође често јављају у својеврсним низовима.

При покушају одређивања семантичких категорија за наведене именице (нпр. грађевински материјали, храна и пиће, текстил и сл.), схватили смо да овако дефинисане семантичке категорије или тешко обухватају све наведене примере (нпр. папир) или да пак обухватају и многе именице које по морфосинтаксичким критеријумима не спадају у градивне (нпр. даска).

Такође, приметили смо да их је једноставније разврстати по појавном облику у ком их срећемо, тј. по агрегатним стањима, ${ }^{7}$ која смо назвали:

${ }^{5}$ Прототипична ранг-листа је она која се у најмањем броју корака може трансформисати у све остале (до $a b c$ се у једном кораку стиже од $a c b$, а у два од $b c a$ ).

${ }^{6}$ Сваки ranking (листа једног испитаника) третиран је као top- $k$, што значи да се сви уноси који се не појављују у нечијој листи третирају као да су на крају листе, али без одређеног редоследа. Дакле, ако је неко поменуо шећер, а није поменуо вино и пиво, рачуна се да је за њега шећер пре вина и шећер пре пива, али вино и пиво нису рангирани за тог испитаника. Однос између вина и пива рачуна се према оним испитаницима који су поменули бар једну од те две лексеме.

${ }^{7}$ Концепт „агрегатног стања” који овде користимо инспирисан је истоименим термином из физике, који подразумева макроскопски облик постојања материје, с тим што су вредности овде наведене осмишљене тако да обухвате значења именица које обрађујемо и њихове појавне облике, 
зрнасто-растресито-чврсто-еластично-мекано-влакнасто-трунасто-сипко-житко-течно-гасовито

Многи ентитети које градивне именице означавају јављају се, наравно, и у више агрегатних стања, а управо та непостојаност је, чини нам се, изразито важна за семантичко одређење градивних именица. Промена агрегатног стања је најчешће последица људске обраде, на путу од појавног облика дате материје у природи до финалног производа спремног за употребу или конзумацију. Та потенцијална променљивост агрегатних стања и чињеница да се сва она означавају истом лексемом јесте оно што градивним именицама омогућава да се перцепирају као слични (мада не нужно истоврсни) ентитети и да се, као последица тога, граматички слично понашају.

Табела 5. Агрегатна стања, број појављивања и прототипичне лексеме

\begin{tabular}{|l|c|c|l|}
\hline $\begin{array}{l}\text { Конзистенција } \\
\text { (агрегатно стање) }\end{array}$ & $\begin{array}{c}\text { Број } \\
\text { појављивања }\end{array}$ & $\begin{array}{c}\text { Различитих } \\
\text { лексема }\end{array}$ & \multicolumn{1}{|c|}{ Прототип(и) } \\
\hline сипко & 454 & 26 & $\begin{array}{l}\text { песак, брамно, } \\
\text { шећер, со }\end{array}$ \\
\hline течно & 334 & 28 & вода, млеко, уле \\
\hline чврсто & 297 & 29 & дрво, камен \\
\hline житко & 289 & 38 & $\begin{array}{l}\text { малтер, бетон, } \\
\text { маст, блато }\end{array}$ \\
\hline мекано & 146 & 20 & свила, кожа, папир \\
\hline влакнасто & 105 & 12 & вуна \\
\hline растресито & 88 & 5 & земла \\
\hline зрнасто & 64 & 18 & $\begin{array}{l}\text { лан, жито, пири- } \\
\text { нач }\end{array}$ \\
\hline еластично & 36 & 9 & гума \\
\hline гасовито & 30 & 7 & ваздух \\
\hline трунасто & 8 & 7 & босиљак \\
\hline
\end{tabular}

а они су свакако скаларно устројени - не постоји нужно објективна и чврста граница између њих. Алтернативни термин би могао бити и конзистенција (као „ступањ чврстоће, густоће, тврдоће чега” - PMC: s. v. конзистенияија). 


\begin{tabular}{|c|c|c|c|}
\hline $\begin{array}{l}\text { Различита } \\
\text { агрегатна стања }\end{array}$ & & & \\
\hline житко-чврсто & 314 & 20 & стакло, пластика \\
\hline сипко-житко & 185 & 14 & цемент, креч \\
\hline влакнасто-мекано & 134 & 8 & памук \\
\hline метал / категоријално & 77 & 5 & метал \\
\hline зрнасто-сипко-течно & 59 & 7 & кафа \\
\hline зрнасто-сипко & 38 & 5 & бибер \\
\hline сипко-течно & 26 & 5 & какао \\
\hline гасовито / категоријално & 11 & 5 & $2 a c$ \\
\hline чврсто/категоријално & 8 & 8 & руда, грађа \\
\hline $\begin{array}{l}\text { хем. термин / катего- } \\
\text { ријално }\end{array}$ & 8 & 8 & база, киселина \\
\hline мекано / категоријално & 8 & 8 & текстил, тканина \\
\hline $\begin{array}{l}\text { сипко-трунасто / кате- } \\
\text { горијално }\end{array}$ & 11 & 7 & зачин \\
\hline $\begin{array}{l}\text { течно / чврсто / гасови- } \\
\text { то / категоријално }\end{array}$ & 9 & 9 & гориво \\
\hline течно / сипко & 5 & 5 & омекиивач \\
\hline трунасто-течно & 5 & 5 & $4 a j$ \\
\hline житко/категоријално & 5 & 5 & каша \\
\hline житко / течно & 5 & 5 & Ђубриво \\
\hline \multicolumn{4}{|l|}{ Тематске групе } \\
\hline метал & 293 & 14 & $\begin{array}{l}\text { злато, сребро, } \\
\text { гвожђе, бакар }\end{array}$ \\
\hline хемијски термин & 30 & 22 & угљеник \\
\hline воће и поврће & 9 & 7 & $\begin{array}{l}\text { кромпир, помо- } \\
\text { раниа }\end{array}$ \\
\hline \multicolumn{4}{|l|}{ Категоријални називи } \\
\hline категоријално & 39 & 12 & метал \\
\hline
\end{tabular}


Код трију тематских група именица денотати имају више појавних облика у природи и више потенцијалних агрегатних стања током обраде, те смо их ипак назвали према хиперонимима - то су (1) називи метала, (2) називи хемијских елемената, једињења и сл. и (3) називи за воће и поврће. ${ }^{8}$

Именице које смо означили са „категоријално” су хипероними чији су субординирани чланови такође различите градивне именице (по броју појављивања у одговорима то су редом: метал, гас, зачин, база, гориво, грађа, каша, киселина, руда, текстил, тканина), због чега су њихови множински облици у језику фреквентнији него код осталих градивних именица. Када се референцијално употребе, међутим, они заправо означавају неки од својих хипонима и тада немају множинске облике (уп. „Морам да сипам гориво”, где се гориво у разговорном језику користи да означи нпр. бензин или дизел, али обично не и плин или метан).

Ако направимо ранг-листу семантичких категорија (тј. агрегатних стања) по броју појављивања, а затим сваку категорију представимо прототипичном градивном именицом са највећим бројем појављивања, добијамо следећи низ:

песак-вода-дрво-метал-блато-папир-вуна-

-земља-жито-гума-ваздух-кромпир-зачин

\section{1. Једна градивна именица у речницима}

Поменута потенцијална променљивост „,агрегатних стања” денотата̂ градивних именица отежава обраду градивних именица у речницима, а понекад је посебно изазовно одредити њихово примарно значење, што ћемо показати на примеру именице кафа и њене обраде у четири речника - РЈАЗУ, РСАНУ, РМС и једнотомном РСЈ. ${ }^{9}$

${ }^{8}$ Промену агрегатног стања код воћа и поврћа посредно помиње и Милка Ивић када образлаже „градивност” у овим семантичким групама: „Границе између света опредмећене и света неопредмећене материје нису, међутим, толико чврсте да не би допуштале извесна померања, и то увек у истом правцу: извесне појаве, упркос тога што на плану стварности постоје као појединачне уобличене материјалне датости бивају ипак одговарајућим граматичким поступком појединих језика приказане као феномени који егземплификују свет неопредмећеног. [...] Ипак, оваква судбина чешће погађа речи којима су именоване поједине врсте поврћа; ово, мислим, због тога што је баш поврће, не воће, махом подложно кувању, а при кувању се његова првобитна 'предметна' структура преобраћа у својеврсну масу, што само може фаворизовати интерпретацију у смислу 'неопредмећене материје"' (Ивић 2008: 19). Ми бисмо напоменули да „појединачне уобличене материјалне датости” постају део „света неопредмећеног” променом агрегатног стања (што је последица нпр. људских поступака у обради), а да су „граматички поступци” ту да би језик осликао промене у ванјезичкој реалности.

${ }^{9}$ Изоставићемо етимолошке напомене и примере наведене у речничким чланцима. Подвлачења су наша. 
Речник ЈАЗУ под одредницом кафа даје следећа значења:

biḷka (Coffea arabica L.), ńezino sjeme, piće što se čini polivši vrelom vodom ispržena zrna od sjemena; pošto u nas nema biḷke, narod upotrebl̦ava ovo ime osobito za treće značeńe (piće), pa i za drugo (zrna pržena i nepržena). - isporedi kahva $i$ kava. [...] a. zrńe (sjeme), i kao trgovina. [...] b. piće. [...] c. biḷka. — S pridjevom diṿ̦a znači drugu biļku. [...] d. vidi kafana. — U naše vrijeme u Dubrovniku. P. Budmani. ${ }^{10}$

(РJA3У: s. v. kafa)

\section{У речнику САНУ кафа се описује као:}

1. а. бот. општи назив за зимзелене биљке Coffea из ф. Rubiaceae од којих се највише гаје C. arabica $и$ C. liberica. б. семе ове билке. в. напитак справљен од прженог и самлевеног семена ове биљке. 2. в. кафана.

(PCAHY: s. v. кaфa $)^{11}$

\section{Према РМС, кафа може бити:}

1. бот. тропска грмолика биљка зрнаста плода Coffea arabica; њезин плод. 2. напитак приређен од пржена кавина плода или његова сурогата. 3. покр. в. кавана.

$(\mathrm{PMC}: \text { s. v. } \kappa а в а=\kappa а ф a)^{12}$

У другом издању једнотомног речника Матице српске стоји да је кафа:

а. бот. назив за зимзелене биљке Coffea из ф. Rubiaceae од којих се највите гаје C. arabica $u$ C. liberica; семе ове билке. б. напитак справљен од прженог и самлевеног семена ове биљке. в. разг. количина кафе (б) која запрема одређену посуду (иољи(ии)у или сл.): попити две кафе.

(PCJ: s. v. кaфa)

На путу од биљке („влакнасто”), тј. њеног плода („воће и поврће”), до напитка („течно”) кафа пролази кроз још два агрегатна стања - „зрнасто” (када се из плода извади семе/зрно, које се онда суши и пече) и „сипко” (када се то печено зрно самеље), која не бележе сви речници. Иако самлевена (и евентуално упакована) кафа није добила своје посебно значење ни у једном речнику, поменута је у РСАНУ и једнотомном РСЈ, у ком је додато и значење са регуларном метонимијом садржавач $=$ садржај ${ }^{13}$ које смо у следећој табели назвали „одмерено".

10 Значење d. (kafana), које ће у каснијим речницима бити означено као покрајинско а у једнотомном речнику изостављено, нема компоненту градивности. Оваква метонимија је, чини нам се, прилично ретка.

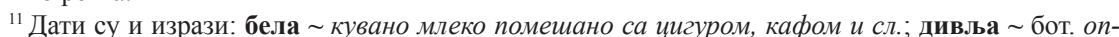
шти назив за биљке Lupinus из ф.Papilionaceae [...]; турска 1) в. кафа (1в). 2) бот. в. дивља кафа; црна $\sim$ в. кафа (1в); швапска ређе скувана кафа, обично са додатком цицуре; шведска бот. биљка Astragalus boeticus из ф. Papilionaceae.

${ }^{12}$ Дат је и израз: бела пиће начињено од млека помешаног с кавом.

${ }^{13}$ Овај тип метонимије могао би се применити и на самлевену кафу у паковању (нпр. „Узми две кафе, требаће нам, идемо у госте”). Питање градивности и бројивости у оваквим конструкцијама биће предмет засебног истраживања. 
Табела 6. Именица кафа у речницима

\begin{tabular}{|l|c|c|c|c|c|c|}
\hline кафа & $\begin{array}{c}\text { „влак- } \\
\text { насто" } \\
\text { (биљка) }\end{array}$ & $\begin{array}{c}\text { „воће и } \\
\text { поврће” } \\
\text { (плод) }\end{array}$ & $\begin{array}{c}\text {,зрна- } \\
\text { сто” } \\
\text { (семе) }\end{array}$ & $\begin{array}{c}\text { „сипко" } \\
\text { (самле- } \\
\text { вено) }\end{array}$ & $\begin{array}{c}\text { „течно” } \\
\text { (напитак) }\end{array}$ & $\begin{array}{c}\text { „одме- } \\
\text { рено” } \\
\text { (шољица) }\end{array}$ \\
\hline РЈАЗУ & с. & - & а. & - & ь. & - \\
\hline РСАНУ & 1. а. & - & 1. б. & $(1$. в. $)$ & 1. в. & - \\
\hline РМС & 1. & 1. & - & - & 2. & - \\
\hline РСЈ & а. & - & а. & (б. $)$ & б. & в. \\
\hline
\end{tabular}

Речници се труде да опишу сва значења речи, што би код градивних именица очигледно подразумевало сва њихова агрегатна стања (укључујући и нпр. називе финалних производа, који су често добијени метонимијом). Одредити које је значење примарно је, рекло би се, помало незахвалан посао.

Реч кафа је у нашој анкети наведена 14 пута. Ми смо јој као агрегатно стање доделили атрибут „зрнасто-сипко-течно” ${ }^{14}$, пошто, наравно, нисмо могли знати који је „појавни облик” кафе сваки од испитаника имао на уму. Које ће значење у језику бити доминантно зависи од више чинилаца - временских, географских и културних (од навика друштва које се језиком служи, али и од навика сваког појединачног говорника). Ономе ко кафу обично конзумира у кафићима (или му је неко приноси), вероватно је „течно” прво пало на памет. За онога ко справља турску кафу сваког јутра, вероватно је кафа пре свега „сипка”. Онај ко је кафу куповао и/или готовио пре 30 година, вероватно је о њој пре свега размишљао као о „зрнастом”, јер ју је морао најпре самлети да би је даље користио. Сматрали смо да су сва три појавна облика „равноправна” и зато смо кафу означили као „зрнасто-сипко-течно”, поштујући притом редослед којим се агрегатна стања смењују приликом обраде. ${ }^{15}$ Посве смо сигурни, међутим, да нико од наших испитаника, када је написао кафа, није имао на уму ни биљку ни њен плод, не зато што испитаници не знају да је свака кафа најпре била биљка, већ зато што смо анкету спровели у Србији (а не, на пример, у Бразилу). Стога је нисмо означили као „влакнасто” или „воће и поврће”.

Већина речника је ипак као прво значење речи кафа навело кафу као биљку, такође пратећи „редослед агрегатних стања у обради”. Само је Речник ЈАЗУ додао сасвим умесну напомену да ,роšto u nas nema biļke, narod upotrebl̦ava ovo ime osobito za treće značeńe (piće), pa i za drugo (zrna pržena i nepržena)".

\footnotetext{
${ }^{14}$ При томе би „течно” могло бити и „одмерено”, али то остављамо за другу прилику, као што смо рекли у претходној напомени.

${ }^{15}$ Што није увек јасно и једносмерно - метали су углавном најпре чврсти, затим житки, да би финални производ био опет чврст; многи хемијски елементи се у природи налазе у различитим агрегатним стањима итд.
} 


\section{5. Погрешни одговори у анкети}

Заједничке именице

Као грешке су се анкети углавном јављале заједничке именице. Неке од грешака су потпуно немотивисане (саксија, мајииа, ливада), док је већина грешака заснована на семантици наведених именица - оне често означавају оно од чега се нешто гради, што улази у састав других ентитета (даска, блок, брвно, стена, влакно, мишић, минерали) или оно што се гради (кућа, зид).

Посебан коментар захтевају именице које означавају храну. Као погрешне смо означили уносе печурка, јаја и коре, пошто имају регуларну једнину и множину и пребројавају се, а градивне именице се традиционално одређују као singularia tantum. Из истог разлога смо одбацили и презле и тестенине, мада сматрамо да и оне спадају у градивне именице. ${ }^{16}$ Наиме, именица презла може се срести и као singularia tantum ${ }^{17}$ и као pluralia tantum. У РСЈ стоји: пре́зла ж нем. (обично у мн.) мрвииа од осушеног и самлевеног хлеба. Видимо да презле, и када cy pluralia tantum, заправо имају облике једнине, али се они ретко користе, па за њих Б. Томић (2014: 43-47) каже: „Сматрамо да је у оваквим случајевима граница између општих и градивних именица слабо изражена”.

Могло би се рећи да градивне именице нису заправо singularia tantum (,,имају само једнинске облике”), већ singularia principaliter (,имају углавном једнинске облике"). Није за њих одређујуће то што немају облике множине, већ то што употреба множинских облика подразумева извесно семантичко померање (као што је „мисли се на врсте”). Исто важи и за оне градивне именице које се обично сврставају у pluralia tantum, а код којих се употребљавају и једнински облици (али ретко, и уз померену семантику; они као да тада имају функцију партикуларизатора или значење сингулатива) - и за њих би, дакле, прикладнији термин можда био pluralia principaliter. Дакле, код градивних именица се или претежно употребљавају облици једнине (који означавају неодређену количину материје, док множински облици означавају врсте) или претежно употребљавају облици множине (који опет означавају неодређену количину материје, док једнински облици врше функцију партикуларизатора). ${ }^{18}$

\section{Збирне именице}

Четири збирне именице јавиле су међу одговорима у нашој анкети. То су: камење, лишће, грање и пруће. Мотивацију за ове грешке видимо у томе што се

${ }^{16}$ Иако код Пипера и Клајна стоји да „именице singularia tantum обухватају [...] градивне именице (млеко, вода, злато) [...].” (Пипер-Клајн 2014: 58), нешто даље у тексту налазимо да „именице pluralia tantum обично значе: [...] 2. градивност (нпр. мекиње) [...]." (ibid.). Приметићемо само да се код singularia tantum помињу градивне именице, а код pluralia tantum - градивност.

${ }_{17}$ „Одрао сам је, испржио, премазао соком од сарделе и уваљао у ситну презлу од хлеба” - према СрпКор2013 (Дима, Александар. Четрдесет и пет витезова. Превео А. М. Поповић. 1964).

${ }^{18}$ Тако би се као градивне именице могли разумети и уноси у анкети лешници и ораси, посебно када су самлевени, иако су овом приликом били означени као грешке. 
нпр. од камења или прућа може нешто и направити, а уз то су и singularia tantum, па не изненађује да су се нашле међу одговорима. Оне су деривати (са збирним суфиксом -je), те нема потребе за партикуларизацијом типичном за градивне именице јер њихове мотивне речи означавају јединичне елементе „материје”. Ипак, осим ових (често помињаних) критеријума, треба пронаћи и друге који би помогли да се утврди да ли се и када ове именице понашају као градивне.

\section{Апстрактне именице}

На списку грешака нашле су се и апстрактне именице. Приметићемо само да су именице температура и притисак обе из домена физике и да су обе у вези са фазним трансформацијама (променом агрегатног стања). И трећа је из домена физике, али означава одсуство сваке материје у неком простору - вакуум је, тако, именица за коју би такође било занимљиво проверити како пролази елабориране критеријуме за одређивање градивних именица.

\section{Један посебан случај}

Из анализе је искључен један испитаник, чији одговори показују да он осећа шта је „градивност”, али не зна шта су „градивне именице” и скрећу пажњу на проблеме који се јављају при разумевању градивних именица као семантичке категорије у оквиру граматичке анализе. Ево свих двадесет одговора овог испитаника:

\begin{tabular}{|c|c|}
\hline $\begin{array}{l}\text { градивни придев + заједничка } \\
\text { именица }\end{array}$ & градивни придев + градивна именица \\
\hline \multirow{3}{*}{$\begin{array}{l}\text { бетонски зид, стаклени зид, плас- } \\
\text { тична кеса, гипсани зид, камени } \\
\text { под, пластични ауто, гвоздена ка- } \\
\text { пија, стаклени прозор }\end{array}$} & воћни сок, млечни намаз \\
\hline & описни придев + градивна именица \\
\hline & слатка кафа, вруће млеко, слана вода \\
\hline $\begin{array}{l}\text { заједничка именица + ОД + градив- } \\
\text { на именица }\end{array}$ & $\begin{array}{l}\text { градивна именица }+ \text { ОД }+ \text { заједничка } \\
\text { именица }\end{array}$ \\
\hline под од дрвета & $\begin{array}{l}\text { џем од јагода, слатко од шљива, колач } \\
\text { од јабука }\end{array}$ \\
\hline $\begin{array}{l}\text { односни придев + заједничка } \\
\text { именица }\end{array}$ & $\begin{array}{l}\text { градивна именица }+C A+\text { градивна } \\
\text { именица }\end{array}$ \\
\hline батеријска лампа & пита са месом, чај са медом \\
\hline
\end{tabular}

Ови одговори нам скрећу пажњу на важан аспект градивности: она означава „од чега је (претежно) X” или „шта је (најјважнији) састојак од X”. Испитаник је наводио синтагме чији је центар $X$, а у атрибутској функцији је дао „материја- 
ле” и „састојке”. ${ }^{19}$ Употреба одређеног придевског вида наводи нас на тумачење да су за овог испитаника наведене синтагме „устаљене”, што може бити у вези са хипонимијом односно таксонимијом везаном за градивне именице.

\section{6. Закључак}

При покушају „разврставања” именица у оквиру поделе по значењу, чим се зађе изван најчешће навођених примера у граматикама, наилази се на проблеме који се не могу лако разрешити уз помоћ најчешће помињаних критеријума при одређивању класе градивних именица (семантичког, морфолошког и синтаксичког). Пошто су градивне именице „категорија са нејасним границама” (Драгићевић 2010: 81), као оријентир у одређивању шта јесте, а шта није градивна именица могао би послужити прототип (односно више њих), са којим би се поредили остали чланови групе.

Резултати анкете коју смо спровели показали су да су за наших 110 испитаника најбољи примери за прототипичне градивне именице песак, вода, брашно и шећер, које је навело преко 80 испитаника. Следе млеко, со, дрво, злато, уље, камен, сребро, земља, стакло, гвожће, пластика, памук, бакар и вуна. Релевантност наведене листе, добијене једноставним пребројавањем појављивања, потврђена је прототипичном ранг-листом добијеном методама за одређивање преференција у подацима.

Покушај одређивања семантичких категорија за око 250 именица које су испитаници навели у анкети (нпр. грађевински материјали, храна и пиће, текстил и сл.), показао нам је да семантичке категорије којима се обично дефинишу градивне именице (а које најчешће у фокус стављају функционални аспект денотата) или тешко обухватају све наведене примере (нпр. папир) или пак обухватају и многе именице које по морфосинтаксичким критеријумима не спадају у градивне (нпр. даска). С друге стране, појавни облици денотата градивних именица, које смо у овом раду назвали „,агрегатна стања” значајно поједностављују груписање градивних именица према семантици, а потенцијална променљивост агрегатних стања и чињеница да се сва она означавају истом лексемом јесте оно што градивним именицама омогућава да се перцепирају као слични (мада не нужно истоврсни) ентитети и да се, као последица тога, граматички слично понашају. Даља разрада оваквог погледа на семантику градивних именица и провера на корпусу могле би, надамо се, помоћи бољем граматичком одређењу класе градивних именица у граматикама (нпр. раздвајањем именица singularia tantum од именица singularia principaliter) и разграничењу градивних именица и других класа, али и допринети бољој обради градивних именица у речницима.

${ }^{19}$ Чак и у одговору у ком нема градивности (батеријска лампа), примећујемо да је батерија оно што је најважнији елемент за идентификацију ове врсте предметаิ, чији је хипероним лампа. 


\section{ЛИТЕРАТУРА}

Драгићевић 2001: Р. Драгићевић, Придеви са значењем људских особина у савременом српском језику, Библиотека Јужнословенског филолога (Нова серија, књ. 18), Београд: Институт за српски језик САНУ

Драгићевић 2010: Р. Драгићевић, Лексикологија српског језика, Београд: Завод за уџбенике.

Ивић 1980: М. Ивић, „О 'партикуларизаторима”,, Јужнословенски филолог, XXXVI, Београд, 1-12.

Ивић ${ }^{3}$ 2008: M. Ivić, „Izbrojivost onoga što imenica označava kao gramatički problem", Lingvistički ogledi, Beograd: Biblioteka XX vek, 13-38.

Ломпар 2016: В. Ломпар, Врсте речи и граматичка пракса (од Вука до данас), Библиотека Књижевност и језик (књ. 49), Београд: Друштво за српски језик и књижевност Србије

Пипер и др. 2005: П. Пипер, И. Антонић, В. Ружић, С. Танасић, Љ. Поповић, Б. Тошовић, Синтакса савременог српског језика: Проста реченица, Београд: Институт за српски језик САНУ - Београдска књига - Матица српска

Пипер-Клајн ${ }^{2} 2014$ : П. Пипер, И. Клајн, Нормативна граматика српског језика, Нови Сад: Матица српска

PJA3У: Rječnik hrvatskoga ili srpskoga jezika, Zagreb: Jugoslavenska akademija znanosti i umjetnosti, 1892-1897.

PМС: Речник српскохрватскога књижевног језика, друго фототипско издање, Књига друга (1967), Нови Сад: Матица српска, Загреб: Матица хрватска, 1990.

РСАНУ: Речник српскохрватског књижевног и народног језика, Београд: Српска академија наука и уметности - Институт за српски језик, 1959-.

PCJ: М. Николић (ур.), Речник српскога језика, измењено и поправљено издање, Нови Сад: Матица српска, 2011.

СрпКор2013: Korpus savremenog srpskog jezika SrpKor2013. Математички факултет Универзитета у Београду. http://www.korpus.matf.bg.ac.rs/ (приступљено септембра 2017).

Стевановић ${ }^{2}$ 1970: М. Стевановић, Савремени српскохрватски језик I, Београд: Научна књига, Београд.

Томић 2014: Б. Томић, „Категорије броја и бројивости у називима за јела у српском језику", Наш језик, XLV/3-4, Београд, 39-49. 
Dina P. Tomić Anić

PROTOTYPICAL MATERIAL MASS NOUNS

Summary

Since the criteria for defining material mass nouns (nomina materialia) found in Serbian grammar books often cannot be unambiguously applied when determining whether individual nouns are to be used in mass syntax or not, in this paper, we try to identify prototypical material mass nouns; once identified, such nouns could consequently be used as reference points in grammatical and semantic analysis of material mass nouns. We especially focus on semantic elements that are crucial for establishing material quality (materiality) in mass nouns. While commenting on results of the survey conducted for the purpose of finding prototypical material mass nouns, we address the problem of distinguishing the class of material nouns from other noun classes usually found in semantic classification of nouns in grammar books.

Key words: materiality, material quality in nouns, material mass nouns, nomina materialia, prototypical material mass nouns, meaning of material mass nouns, semantic classification of nouns, singularia tantum. 